\title{
Systemic vasculitis with dermatomyositis, hearing loss, neuropathy, and multiorgan dysfunction
}

Figure Nerve and muscle biopsy
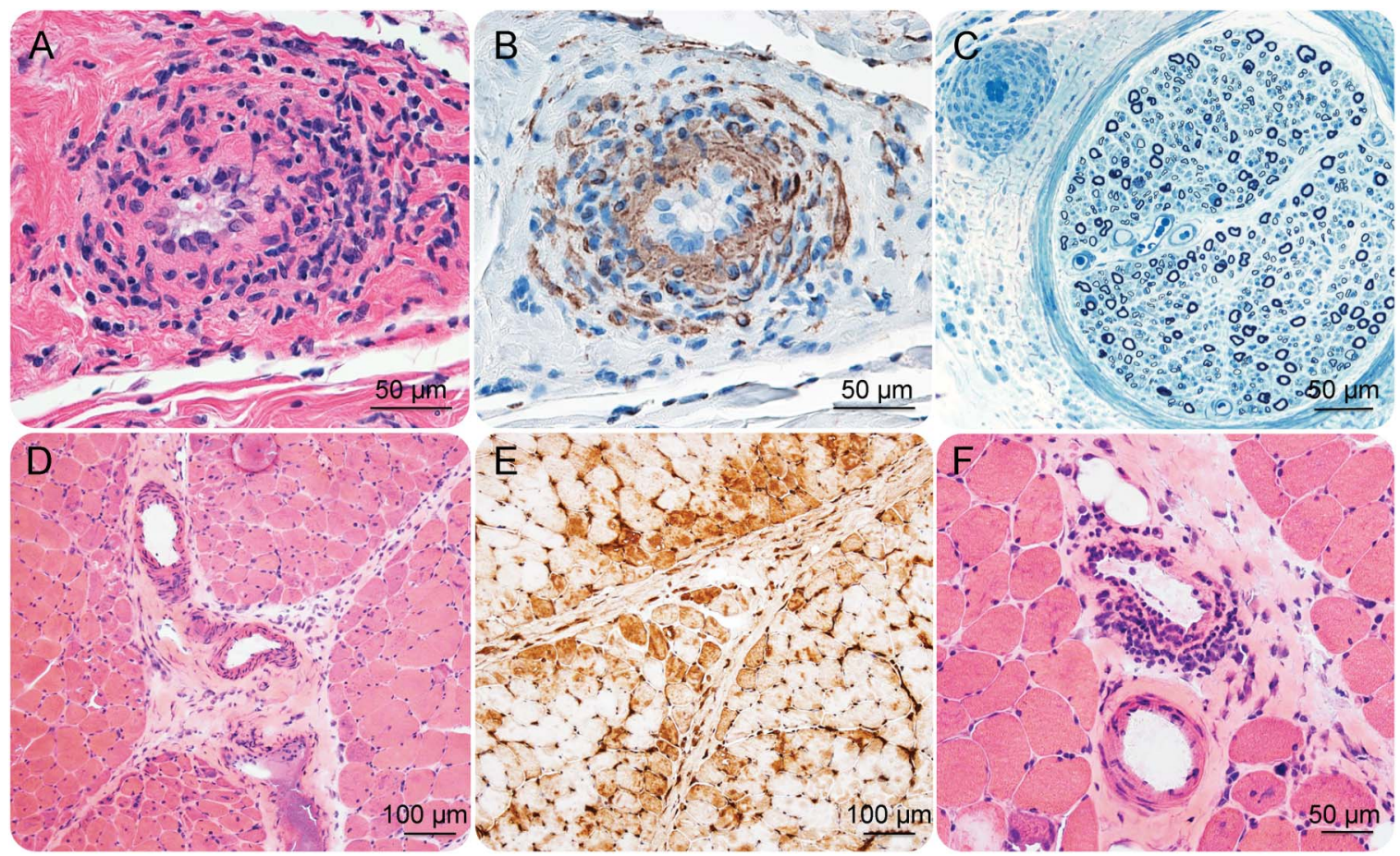

Nerve: (A) Hematoxylin \& eosin (H\&E) stain: inflammatory cells invading an epineurial arteriole; (B) smooth muscle actin immunostain: vessel wall fragmentation; (C) epoxy section: mildly reduced fiber density and epineurial vessel wall infiltration. Muscle: H\&E stain: (D) perifascicular fiber atrophy and (F) perimysial perivascular inflammation; $(E)$ myxovirus resistance $A(M x A)$ immunostain: perifascicular sarcoplasmic expression of MxA. ${ }^{1}$

A 39-year-old woman presented with 10 months of steadily progressive weakness, myalgia, weight loss, and intermittent feet tingling. During the course of her illness, she developed refractory atrial fibrillation, left followed by right-sided hearing loss, amenorrhea, and hematuria. She had been on rituximab for years for "polyarthralgias," which was stopped at symptom onset. Examination showed severe proximal weakness and mildly decreased toe proprioception. Deltoid biopsy (figure) was diagnostic of dermatomyositis. Liver and enteric biopsies showed lymphocytosis. Suspicion for vasculitis led to sural nerve biopsy (figure), showing large-arteriole vasculitis. Despite treatment with high-dose prednisone and cyclophosphamide, the patient died. This is a unique case of systemic vasculitis associated with dermatomyositis, hearing loss, neuropathy, and multiorgan dysfunction. The histologic findings and the relentless progression despite stopping rituximab argue against a role for rituximab in the pathogenesis.

Priya S. Dhawan, $M D,{ }^{*}$ P. James B. Dyck, $M D$, Jennifer A. Tracy, MD, Elie Naddaf, $M D^{*}$

*These authors contributed equally to this work.

From the Department of Neurology, Mayo Clinic, Rochester, MN.

Author contributions: Dr. Dhawan: conception and design, analysis and interpretation of data, drafting and revising article, final approval of submitted version. Dr. Dyck: drafting and revising article, final approval of submitted version. Dr. Tracy: drafting and revising article, final approval of submitted version. Dr. Naddaf: conception and design, analysis and interpretation of data, drafting and revising article, final approval of submitted version. 
Study funding: No targeted funding reported.

Disclosure: The authors report no disclosures relevant to the manuscript. Go to Neurology.org for full disclosures.

Correspondence to Dr. Naddaf: Naddaf.elie@mayo.edu

1. Uruha A, Nishikawa A, Tsuburaya RS, et al. Sarcoplasmic MxA expression: a valuable marker of dermatomyositis. Neurology 2017;88:493-500.

\section{WriteClick ${ }^{\circledR}$ rapid online correspondence}

The editors encourage comments about recent articles through WriteClick:

Go to Neurology.org and click on the "WriteClick" tab at the top of the page. Responses will be posted within 72 hours of submission.

Before using WriteClick, remember the following:

- WriteClick is restricted to comments about studies published in Neurology within the last eight weeks

- Read previously posted comments; redundant comments will not be posted

- Your submission must be 200 words or less and have a maximum of five references; reference one must be the article on which you are commenting

- You can include a maximum of five authors (including yourself)

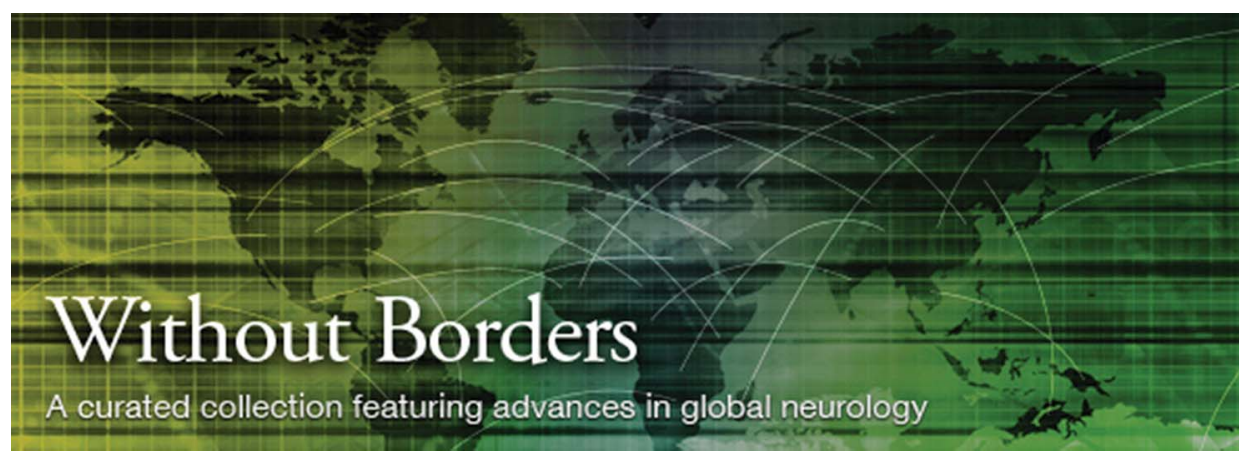

\section{Without Borders - A curated collection featuring advances in global neurology}

This Neurology ${ }^{\circledR}$ special interest Web site is the go-to source for tracking science and politics of neurology beyond the United States, featuring up-to-the-minute blogs, scholarly perspectives, and academic review of developments and research from Neurology journals and other sources. Curated by Gretchen L. Birbeck, MD, MPH.

Expand your world view at Neurology.org/woborders. 


\section{Neurology}

\section{Systemic vasculitis with dermatomyositis, hearing loss, neuropathy, and multiorgan dysfunction \\ Priya S. Dhawan, P. James B. Dyck, Jennifer A. Tracy, et al. Neurology 2017;89;2119-2120 \\ DOI 10.1212/WNL.0000000000004656}

This information is current as of November 13, 2017

\section{Updated Information \&} Services

References

Subspecialty Collections

Permissions \& Licensing

Reprints including high resolution figures, can be found at: http://n.neurology.org/content/89/20/2119.full

This article cites 1 articles, 1 of which you can access for free at: http://n.neurology.org/content/89/20/2119.full\#ref-list-1

This article, along with others on similar topics, appears in the following collection(s):

Peripheral neuropathy

http://n.neurology.org/cgi/collection/peripheral_neuropathy Vasculitis

http://n.neurology.org/cgi/collection/vasculitis

Information about reproducing this article in parts (figures,tables) or in its entirety can be found online at:

http://www.neurology.org/about/about_the_journal\#permissions

Information about ordering reprints can be found online:

http://n.neurology.org/subscribers/advertise

Neurology ${ }^{\circledR}$ is the official journal of the American Academy of Neurology. Published continuously since 1951, it is now a weekly with 48 issues per year. Copyright (O 2017 American Academy of Neurology. All rights reserved. Print ISSN: 0028-3878. Online ISSN: 1526-632X.

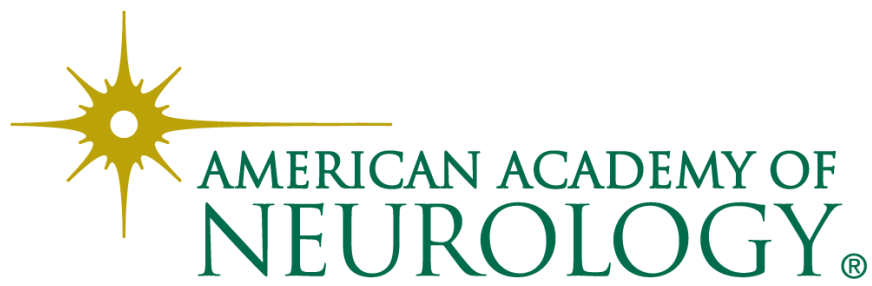

